\title{
Effect of Irrigation and Mulching on Growth, Yield and Water Use Efficiency of Potato
}

\author{
S.N. Dash, Y. Pushpavathi" and S. Behera \\ Department of Horticulture, OUAT, Bhubaneswar-751003, India \\ *Corresponding author
}

\section{A B S T R A C T}

\section{Keywords}

Potato, Irrigation, Mulch, Tuber yield, Water use efficiency, Economics

Article Info

Accepted:

24 January 2018

Available Online:

10 February 2018

Potato is grown in winter months under irrigation in Odisha. The crop has a high water requirement for obtaining good yield. On the other hand, excess irrigation reduces yield and increases production costs. In the present study to assess the effects of irrigation and mulching in potato production, plant emergence and number of shoots per plant were not affected by irrigation and mulching levels. Plant height and number of leaves were significantly affected by the treatments. Frequent irrigation at $30 \mathrm{~mm}$ CPE yielded maximum $22.632 \mathrm{t} \mathrm{ha}^{-1}$ of total tubers and $18.006 \mathrm{t} \mathrm{ha}^{-1}$ of marketable tubers. Water use efficiency was low $\left(39.9 \mathrm{~kg} \mathrm{ha}-\mathrm{mm}^{-1}\right)$ at high irrigation frequency and high $\left(48.8 \mathrm{~kg}\right.$ ha- $\left.\mathrm{mm}^{-1}\right)$ at low irrigation frequency. Irrigation at $35 \mathrm{~mm}$ CPE resulted in maximum total return ('140001), net return ( 71853$)$ and cost benefit ratio (2.03).

\section{Introduction}

Potato (Solanum tuberosum L.) is one of the most important and widely consumed vegetables in Odisha. However, there has been a wide gap in its production and demand in the state. The crop is grown in almost all the districts of the state. The growing season of the crop is characterized by cool dry winter climate necessitating regular irrigation from tuber planting till the near tuber maturity for higher yield. Water has been recognized as an important manageable input influencing potato tuber growth, quality and yield. The crop has a high water requirement which is positively correlated with yield of tubers. This has been well established in chipping potato cultivars under west-central Indian plains (Kumar et al., 2007). On the other hand, excess irrigation increases production costs, reduces yield by affecting soil aeration, root respiration and increasing the occurrence of diseases and pests. Deficit irrigation lowers yield due to reduced leaf area and/or reduced photosynthesis per unit leaf area (Van Loon, 1981). Crops sensitive to water stress require a systematic approach for irrigation scheduling. Evapotranspiration in potato is important in scheduling irrigation to improve the effectiveness of irrigation water. Mulching 
also helps in faster plant emergence; early canopy development of potato plants and higher marketable and total tuber yield (Mohammad et al., 2002). Therefore, selection of proper irrigation schedules and mulching practices in potato may be an important resource management tool in improving water use efficiency in potato production. In view of these an experiment was undertaken to optimize the irrigation and mulch requirements for higher tuber productivity.

\section{Materials and Methods}

The study was conducted at the experimental plots of All Coordinated Research Project on Potato, OUAT, Bhubaneswar during rabi seasons of 2007-08 and 2008-09. The experiment area is located at $20^{\circ} 15^{\prime} \mathrm{N}$ latitude and $85^{\circ} 52^{\prime} \mathrm{E}$ longitude and is about $60 \mathrm{~km}$ away from Bay of Bengal with an altitude of $25.5 \mathrm{~m}$ above MSL. The soil of the experimental plot was sandy loam with a $\mathrm{pH}$ of 5.6, low in organic carbon $(0.52 \%)$, low in available $\mathrm{N}\left(228.4 \mathrm{~kg} \mathrm{ha}^{-1}\right)$, medium in both available $\mathrm{P}\left(20.4 \mathrm{~kg} \mathrm{ha}^{-1}\right)$ and available $\mathrm{K}$ $\left(89.9 \mathrm{~kg} \mathrm{ha}^{-1}\right)$. The four replications of the treatments were arranged in a factorial randomized block design. The treatments were the combination of different levels of irrigation and mulching. The twelve treatments comprised of a combination of five irrigation levels ( $\mathrm{I}_{1}$ to $\mathrm{I}_{5}$ ), viz. 30, 35, 40, 45 and $50 \mathrm{~mm}$ CPE (cumulative pan evaporation) and a control $\left(\mathrm{I}_{6}\right.$, irrigation at critical stages only, viz. stolon formation, tuber initiation and tuber development stages) and two levels of mulch i.e. $\mathbf{M}_{1}$, with and $\mathbf{M}_{2}$, without paddy straw mulch. A largely grown local variety, Kufri Jyoti, with crop duration of 90-100 days was used as the test variety. Well sprouted foundation seed tubers were planted in plots of size $4.8 \mathrm{~m} \times 3.6 \mathrm{~m}$ at spacing of $60 \mathrm{~cm} \times 20$ $\mathrm{cm}$ in the $3^{\text {rd }}$ week of November in both the years. One post planting and one subsequent irrigation common to all treatments were applied to facilitate uniform and timely emergence of plants. The subsequent irrigations were applied through ridge and furrow method as per the treatment (Table 1). In each irrigation $50 \mathrm{~mm}$ water was applied. Paddy straw mulch was applied as per treatment @ 5 tonnes per hectare on fresh weight basis at 25 days after planting. Recommended doses of fertilizers @ $120 \mathrm{~kg}$ $\mathrm{N}, 80 \mathrm{~kg} \mathrm{P}_{2} \mathrm{O}_{5}$ and $100 \mathrm{~kg} \mathrm{~K}_{2} \mathrm{O} \mathrm{ha}^{-1}$ was applied. Half of $\mathrm{N}$ and full $\mathrm{P}_{2} \mathrm{O}_{5}$ and $\mathrm{K}_{2} \mathrm{O}$ were placed in bands below seed tubers at the time of planting and remaining half dose of $\mathrm{N}$ was applied at the time of earthing up.

The plant emergence count was made thirty days after planting tubers. All necessary plant protection measures were adopted for raising a successful crop. Growth characters of the plants like plant height, number of stems per plant and number of compound leaves per plant were recorded just before cutting the haulm. The crop was dehaulmed at 85 days after planting (DAP) and harvesting was done one week later.

The harvested tubers were graded into two categories, i.e. small tubers $(<50$ grams $)$ and marketable tubers (> 50 grams). Water use efficiency (WUE) was calculated using the following formula:

WUE $\left(\mathrm{kg} \mathrm{ha- \textrm {mm } ^ { - 1 } )}=\frac{\text { Tuber yield }\left(\mathrm{kg} \mathrm{ha}^{-1}\right)}{\text { Water applied through irrigation }(\mathrm{mm})}\right.$

The cost of cultivation varied according to the treatments. The variable components in the cost of inputs were that of variable irrigation water and its application and the cost of mulch material. Total return corresponds to the value of harvested crop. B: C ratio refers to the return per rupee invested. For economic analysis cost of all the inputs in the local market and sale price of produce at the farm gate has been used. 


\section{Results and Discussion}

\section{Growth attributes}

\section{Plant emergence}

Plant emergence was not significantly affected due to either the various levels of irrigation or mulching (Table 2) which has also been confirmed by the findings of Sadawarti et al., (2013). The mean percentage of plant emergence varied from a minimum of 90.96 with irrigation at $30 \mathrm{~mm} \mathrm{CPE} \mathrm{to} \mathrm{a} \mathrm{maximum}$ of 93.02 at $50 \mathrm{~mm} \mathrm{CPE}$.

\section{Plant height}

Plant height was significantly higher in all the irrigation treatments over control. Highest plant height $(48.81 \mathrm{~cm})$ was recorded at 30 $\mathrm{mm}$ CPE which was significantly higher over that at 40, 45 and $50 \mathrm{~mm} \mathrm{CPE}$ and control.

There was a gradual decline in this character as the quantity of irrigation water decreased. Patel and Patel (2001) also observed a similar trend of decreasing plant height with reduced irrigation levels in Gujarat potato growing conditions. The plant heights at both 30 and $35 \mathrm{~mm}$ CPE were at par indicating that irrigating the field sooner than $35 \mathrm{~mm}$ pan evaporation was not advantageous. Mulching also increased plant height $(45.24 \mathrm{~cm})$ significantly over no mulch treatment. The beneficial effects of mulching in increasing plant height have also been reported by Kar and Kumar (2007).

\section{Foliage growth}

Shoot number per plant was not affected significantly by different irrigation levels or mulching. However, number of compound leaves per plant was influenced by both different irrigation and mulching treatments. Irrigation at $30 \mathrm{~mm}$ CPE resulted in highest number of leaves (52.69) and was at par with $35 \mathrm{~mm}$ CPE. The lowest number of leaves (46.05) was observed in the control plots. Mulching also resulted in significantly higher leaf number (50.36) than no mulching (47.34).

\section{Yield attributes}

\section{Tuber yield}

Small tubers $(<50 \mathrm{~g})$, marketable tubers $(>50$ g) and total tubers yield were significantly affected by both different irrigation and mulching levels (Table 2). All the irrigation levels gave significantly higher yields in all the tuber yield categories over the control. Irrigation at $35 \mathrm{~mm}$ CPE resulted in highest tuber yield in all the tuber weight categories.

Table.1 Details of irrigation treatments and water used

\begin{tabular}{|c|c|c|c|c|c|c|}
\hline \multirow{2}{*}{$\begin{array}{l}\text { Irrigation } \\
\text { treatment }\end{array}$} & \multirow{2}{*}{$\begin{array}{c}\text { Irrigatio } \\
\text { n levels } \\
\text { (mm } \\
\text { CPE) }\end{array}$} & \multicolumn{2}{|c|}{ 2007-08 } & \multicolumn{2}{|c|}{ 2008-09 } & \multirow{2}{*}{$\begin{array}{c}\text { A verage } \\
\text { water used } \\
(\mathbf{m m})\end{array}$} \\
\hline & & $\begin{array}{l}\text { No. of } \\
\text { irrigations }\end{array}$ & $\begin{array}{c}\text { Water } \\
\text { used } \\
(\mathrm{mm})\end{array}$ & $\begin{array}{l}\text { No. of } \\
\text { irrigations }\end{array}$ & $\begin{array}{l}\text { Water } \\
\text { used } \\
(\mathrm{mm})\end{array}$ & \\
\hline $\mathbf{I}_{1}$ & 30 & 10 & 500 & 12 & 600 & 550 \\
\hline $\mathbf{I}_{2}$ & 35 & 9 & 450 & 11 & 550 & 500 \\
\hline $\mathbf{I}_{3}$ & 40 & 9 & 450 & 10 & 500 & 475 \\
\hline $\mathbf{I}_{4}$ & 45 & 8 & 400 & 9 & 450 & 425 \\
\hline $\mathbf{I}_{5}$ & 50 & 7 & 350 & 9 & 450 & 400 \\
\hline$I_{6}$ & Control & 6 & 300 & 6 & 300 & 300 \\
\hline
\end{tabular}


Table.2 Effect of mulching and irrigation schedules on growth and yield attributes (pooled over two years)

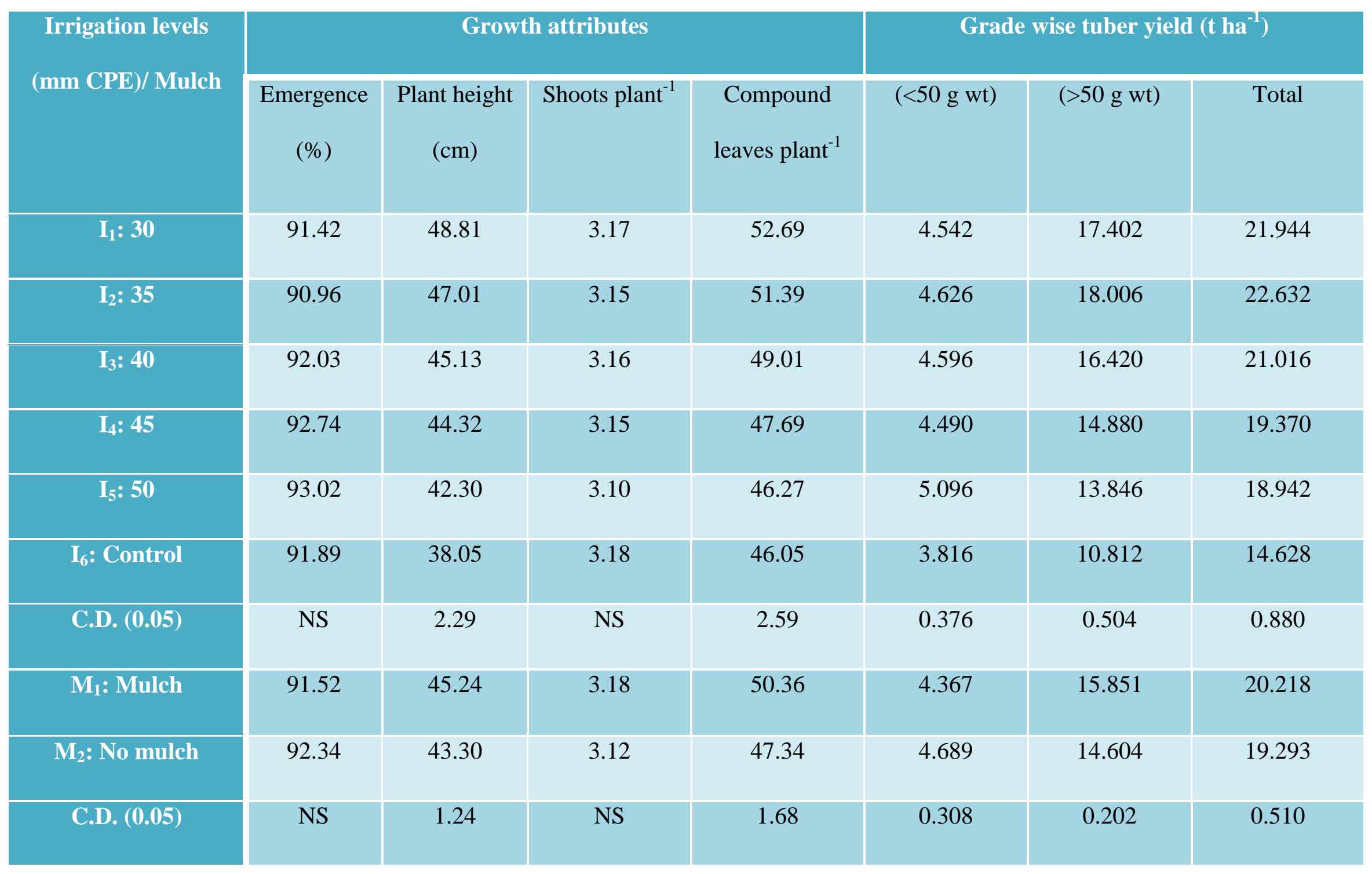


Table.3 Tuber yield, water use efficiency (WUE) and economics of potato production

\begin{tabular}{|c|c|c|c|c|c|}
\hline \multirow{2}{*}{$\begin{array}{c}\text { Levels of } \\
\text { irrigation } \\
(\mathrm{mm} \text { CPE)/ Mulch } \\
\end{array}$} & \multirow{2}{*}{$\begin{array}{c}\text { Total tuber } \\
\text { yield } \\
\left(\mathbf{t} \mathbf{h a}^{-1}\right)\end{array}$} & \multirow{2}{*}{$\begin{array}{c}\text { WUE } \\
\left(\mathrm{kg} \mathrm{ha-mm}^{-1}\right)\end{array}$} & \multicolumn{3}{|c|}{ Economics } \\
\hline & & & $\begin{array}{c}\text { Total return } \\
\left(\mathrm{ha}^{-1}\right)\end{array}$ & $\begin{array}{l}\text { Net return } \\
\left(\mathrm{ha}^{-1}\right)\end{array}$ & $\begin{array}{l}\text { B:C } \\
\text { Ratio }\end{array}$ \\
\hline$I_{1}: 30$ & 21.944 & 39.9 & 117655 & 48979 & 1.70 \\
\hline$I_{2}: 35$ & 22.632 & 45.3 & 140001 & 71853 & 2.03 \\
\hline$I_{3}: 40$ & 21.016 & 44.2 & 117581 & 51969 & 1.70 \\
\hline$I_{4}: 45$ & 19.37 & 45.6 & 107199 & 40906 & 1.56 \\
\hline$I_{5}: 50$ & 18.942 & 47.4 & 102420 & 35782 & 1.49 \\
\hline$I_{6}:$ Control & 14.628 & 48.8 & 89218 & 21359 & 1.30 \\
\hline C.D. (0.05) & 0.88 & 4.4 & - & - & - \\
\hline $\mathrm{M}_{1}$ : Mulch & 20.218 & 45.8 & 117616 & 36448 & 1.71 \\
\hline $\mathrm{M}_{2}$ : No mulch & 19.293 & 43.7 & 107075 & 29408 & 1.55 \\
\hline C.D. (0.05) & 0.51 & 2.5 & - & - & - \\
\hline
\end{tabular}

Under this treatment the total yield $(22.632 \mathrm{t}$ $\left.\mathrm{ha}^{-1}\right)$ and the small tuber yield (4.626 $\left.\mathrm{t} \mathrm{ha}^{-1}\right)$ were at par with those $\left(21.944 \mathrm{t} \mathrm{ha}^{-1}\right.$ and $4.542 \mathrm{t} \mathrm{ha}^{-1}$, respectively) at $30 \mathrm{~mm}$ CPE. Such a result has been supported by the findings of Sadawarti et al., (2013). Kumar et al., (2003) has also suggested that potato leaves close their stomata at relatively low soil moisture regime leading to faster decrease in photosynthesis and transpiration rate than other field crops leading to lower yields which has also been reflected in the present study. Mulching also resulted in higher tuber yield in all the yield categories over no mulching. Such beneficial effects of mulching have been demonstrated in the results achieved by Kar and Kumar (2007).

\section{Water Use Efficiency (WUE)}

An almost linear increase in WUE was observed in response to water stress (Table 3). The lowest WUE (39.9 kg ha- $\mathrm{mm}^{-1}$ ) was obtained where irrigation frequency was highest (30 $\mathrm{mm} \mathrm{CPE),} \mathrm{while} \mathrm{the} \mathrm{highest} \mathrm{WUE}$

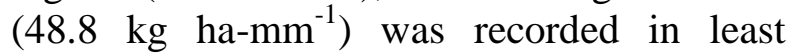
frequently irrigated plots (control treatment involving irrigations only at critical stages of stolon formation, tuber initiation and tuber development). This is in conformity with the findings of Saikia et al., (2011) who reported highest water use efficiency in application of irrigation at stolon formation, tuber formation and tuber development stages. However, the WUE of irrigations at 35, 40, 45 and $50 \mathrm{~mm}$ CPE were at par. Mulching recorded higher WUE (45.8 kg ha- $\mathrm{mm}^{-1}$ ) over no mulching $\left(43.7 \mathrm{~kg}\right.$ ha- $\left.\mathrm{mm}^{-1}\right)$ which is in agreement with the results of Kar and Kumar (2007).

\section{Economics}

Analysis of economics in the present study indicated highest total return and net return of ' $140001 \mathrm{ha}^{-1}$ and $71853 \mathrm{ha}^{-1}$, respectively, with irrigation at $35 \mathrm{~mm}$ CPE (Table 3). The control with irrigation at critical stages fetched lowest net return of $35782 \mathrm{ha}^{-1}$. Mulching treatment gave a higher mean net return of 36448 ha $^{-1}$ over no mulching with $29408 \mathrm{ha}^{-1}$. The higher net income obtained with irrigations at $35 \mathrm{~mm}$ CPE were mainly due to higher tuber yields. The highest value (2.03) of benefit cost ratio (B:C) was observed in irrigation at $35 \mathrm{~mm} \mathrm{CPE}$ resulting from a high tuber yield $\left(22.632 \mathrm{t} \mathrm{ha}^{-1}\right)$ and comparatively lower quantity of water (500 $\mathrm{mm}$ ) used. 


\section{Acknowledgements}

The authors sincerely acknowledge the financial assistance received from the ICAR in conducting the research work.

\section{References}

Kar, G. and Kumar, A. 2007. Effects of irrigation and straw mulch on water use and tuber yield of potato in eastern India. Agril Water Management. 94(13): 109-16.

Kumar, D., J.S. Minhas and Singh, B. 2003. Abiotic stress and potato production. In: The Potato: Production and Utilization in Sub Tropics (Eds) S.M.P. Khurana, J.S. Minhas and S.K. Pandey. Mehta Publishers, New Delhi, India: 314-22.

Kumar, P, S.K. Pandey, S.V. Singh and Kumar, D. 2007. Irrigation requirement of chipping potato cultivars under west- central Indian plains. Potato J. 34: 19398.

Mohammad, M.M., K. Farooq, A. Hussain and Sher, R. 2002. Effect of mulching on growth and yield of potato crop. Asian J. Pl. Sci. 2: 132-33.

Patel, J.C. and Patel, L.R. 2001. Effect of irrigation and nitrogen on yield attributes of potato. J. Indian Potato Assoc. 28: 285-87.

Sadawarti, M.J., S.P. Singh, Vinod Kumar and Lal, S.S. 2013. Effect of mulching and irrigation scheduling on potato cultivar Kufri Chipsona-1 in Central India. Potato J. 41 (1): 65-71.

Saikia, M. 2011. Effect of irrigation and mulching on growth, yield and water use efficiency of potato in Assam. Potato J. 38(1): 81-83.Van Loon, C.D. 1981. The effect of water stress on potato growth, development and yield. Am. Potato J. 58: 51-69.

\section{How to cite this article:}

Dash, S.N., Y. Pushpavathi and Behera, S. 2018. Effect of Irrigation and Mulching on Growth, Yield and Water Use Efficiency of Potato. Int.J.Curr.Microbiol.App.Sci. 7(02): 2582-2587. doi: https://doi.org/10.20546/ijcmas.2018.702.314 